\title{
Modelling artisanal coastal fisheries of Galicia (NW Spain) based on data obtained from fishers: the case of Octopus vulgaris*
}

\author{
JAIME OTERO, FRANCISCO ROCHA, ÁNGEL F. GONZÁLEZ, \\ JOAQUÍN GRACIA and ÁNGEL GUERRA
}

ECOBIOMAR, Instituto de Investigaciones Marinas, C/ Eduardo Cabello 6, 36208 Vigo, Spain.

E-mail: jotero@iim.csic.es

\begin{abstract}
SUMMARY: The small-scale common octopus (Octopus vulgaris) fishery in Galician waters (NW Spain) was studied using a model based on information obtained from fishers. The Gómez-Muñoz model was applied using information obtained from the artisanal Galician fleet from 1998 to 2000. This information was used to estimate catches per unit of effort (CPUE) and total catch for the whole directed creel fishery. A total of 73 interviews were conducted in 22 ports in the west part of ICES division VIIIc and 75 interviews in 16 ports in the north part of ICES division IXa. The estimated total catch during the fishing season for the whole Galician fleet was $5214 \mathrm{t}$ (2528 $\mathrm{t}$ in VIIIc and $2686 \mathrm{t}$ in IXa), and the average CPUE for the VIIIc and IXa fishing grounds obtained from the model was 44.11 and $23.83 \mathrm{~kg} \mathrm{haul}^{-1}$ respectively. To test the reliability of the model, the outputs obtained for a subset of 35 ports (19 in VIIIc and 16 in IXa), were compared with the official statistics of these ports. The average official catch from 1997 to 2000 and estimated total catch data were significantly correlated.
\end{abstract}

Keywords: Octopus vulgaris, small-scale fisheries, Gómez-Muñoz model, catch estimations, NW Spain.

RESUMEN: Modelado de las Pesquerías artesanales Costeras de Galicia (NO España) basándose en INFORMaCión OBTENIDA DE LOS PESCADORES: EL CASO DE OCTOPUS VULGARIS. - La pesquería artesanal de pulpo común (Octopus vulgaris) en aguas de Galicia (NO España) se estudió usando un modelo basado en información obtenida de los pescadores. Para estimar capturas por unidad de esfuerzo (CPUE) y capturas totales en la pesquería dirigida al pulpo común se aplicó el modelo de Gómez-Muñoz, utilizando información de la flota artesanal gallega desde 1998 a 2000. Se hicieron un total de 73 entrevistas en 22 puertos pertenecientes a la división VIIIc oeste de ICES y 75 entrevistas en 16 puertos de la división IXa norte. Las capturas totales estimadas para toda la flota gallega durante la temporada de pesca fueron de $5214 \mathrm{t}(2528 \mathrm{t}$ en VIIIc y $2686 \mathrm{t}$ en IXa), y las CPUE medias para los caladeros VIIIc y IXa obtenidas por el modelo fueron de 44.11 y $23.83 \mathrm{~kg}$ lance ${ }^{-1}$, respectivamente. Para evaluar la fiabilidad del modelo se compararon los resultados estimados en 35 puertos (19 en VIIIc y 16 en IXa) con datos oficiales disponibles. La captura media oficial entre 1997 y 2000, y las capturas totales estimadas estaban significativamente correlacionadas.

Palabras clave: Octopus vulgaris, pesquería artesanal, modelo de Gómez-Muñoz, estimación de capturas, NO España.

\section{INTRODUCTION}

The common octopus, Octopus vulgaris (Cuvier, 1797), is the most important commercially harvest-

*Received June 21, 2004. Accepted February 25, 2005. ed octopus species (Josupeit, 2000). To date, most of the studies published on the $O$. vulgaris fishery refer to time-series analyses of monthly catches (Quetglas et al., 1998), or trends in landings and effort over a long period of time (Sánchez and Obarti, 1993; Hernández-García et al., 1998; 
Tsangridis et al., 2002). However, few studies have been made on fishery management, and these have generally been based on classical finfish models of population dynamics (Hatanaka, 1979; Pereiro and Bravo de Laguna, 1979; Jouffre et al., 2002), which are more appropriate for highly mobile demersal and pelagic resources and for managing industrial fisheries (Caddy, 1999), than for modelling the population dynamics of invertebrate species (Perry et al., 1999). Therefore, new management measures and policies must be applied (Freire and García-Allut, 2000; Freire et al., 2002).

Galicia is the main fishing region of Spain and one of the largest in the European Union (EU). Small-scale coastal fisheries in Galicia are very complex and are very important from socio-economic, cultural and ecological perspectives as Freire and García-Allut (2000), showed in their detailed study of Galician artisanal fisheries. According to the official census of the Galician artisanal fishing fleet updated in 2004, there were almost 5000 vessels operating in numerous coastal embayments (known as "Rías") and shallow oceanic areas. Moreover, these small-scale fisheries are multispecies and utilize a wide variety of gears. Cephalopods (octopus, cuttlefish and squid) are one of the most important resources in this area, and the O. vulgaris fishery is the largest in terms of volume of catches.

To date, there is an absolute lack of specific exploitation plans or co-management in Galicia for this species. This is due to the complexity of the small-scale fisheries in these waters with a large number of human factors and components involved in the fishing activity (see Freire and García-Allut, 2000). Since 1994, the Galician Government has run a comprehensive program in order to collect complete fishery statistics for the artisanal sector ("Servicio de Información Pesquera", SIP, nowadays "Plataforma Tecnológica de la Pesca", www.pescadegalicia.com). However, this information is incomplete and does not provide the standards of quality and detail needed for an effective management plan for octopus or any other resource (Molares and Freire, 2003).

Different methodologies and models have been proposed and applied to estimate CPUE in smallscale fisheries (Gómez-Muñoz, 1990; Hoening et al., 1997; Pollock et al., 1997; Kirchner and Beyer, 1999; Neis et al., 1999). Gómez-Muñoz (1990), developed a simple model to estimate CPUE and total catch in multi-species small-scale fisheries. This model has been applied previously to the hand-jig squid fishery of the north-western Iberian Peninsula (Simón et al., 1996). Rocha et al. (2004), evaluated the model's reliability and accuracy by applying it to the monkfish trawl fishery carried out by the coastal offshore and Grand Sole Galician fleet. The Gómez-Muñoz model involves surveying ship-owners, skippers, fishermen and other personnel related to the fishing sector. The information obtained from the personal interviews provides the data required for the basic model input parameters. The model is then applied to estimate the CPUE and total catch during the fishing season.

The small-scale fishery of $O$. vulgaris operating off the Galician coast is very important from a socio-economic perspective. It yields an average annual catch of about $4000 \mathrm{t}$ with an ex-vessel value of 13 million euros. The various local artisanal gears employed in the octopus fishery were described in Guerra (1997); the creel is the main gear used. The small-scale octopus fishery targets this species to a maximum depth of $150 \mathrm{~m}$ throughout Galician waters, including the Rías. The vessels range from 0.3 to 46.6 gross registered tonnage (grt), with a mean of 4.1 grt. Boat lengths range between 3 and $20 \mathrm{~m}$, with a mean of $7.8 \mathrm{~m}$. One to five fishermen make up the crew depending on the size of the boats. Until September 2000 a total of 1440 boats were permitted to use common octopus creels. However, $98 \%$ of those vessels did not register this gear exclusively, but also used different gears for targeting other species. The autonomous government (Xunta de Galicia) allows up to a maximum of five gears per vessel, and the owners, in accordance with the law (DOG, 04/11/2004), must inform the authorities when they change their gear type during the fishing season. Unfortunately, this information is not accessible and thus, it is impossible to determine the precise effective effort in terms of number of vessels targeting this species in each port.

The aim of this paper is to estimate CPUE and total catch levels of the artisanal common octopus fishery along the entire Galician coast (NW Spain), using a model based on a short interview survey. To test the reliability of the model, the estimated total catch was compared in a subset of ports with official catch data. Mismatching in the amount of catches of this species is discussed within the context of the complexity of the Galician small-scale fisheries. 


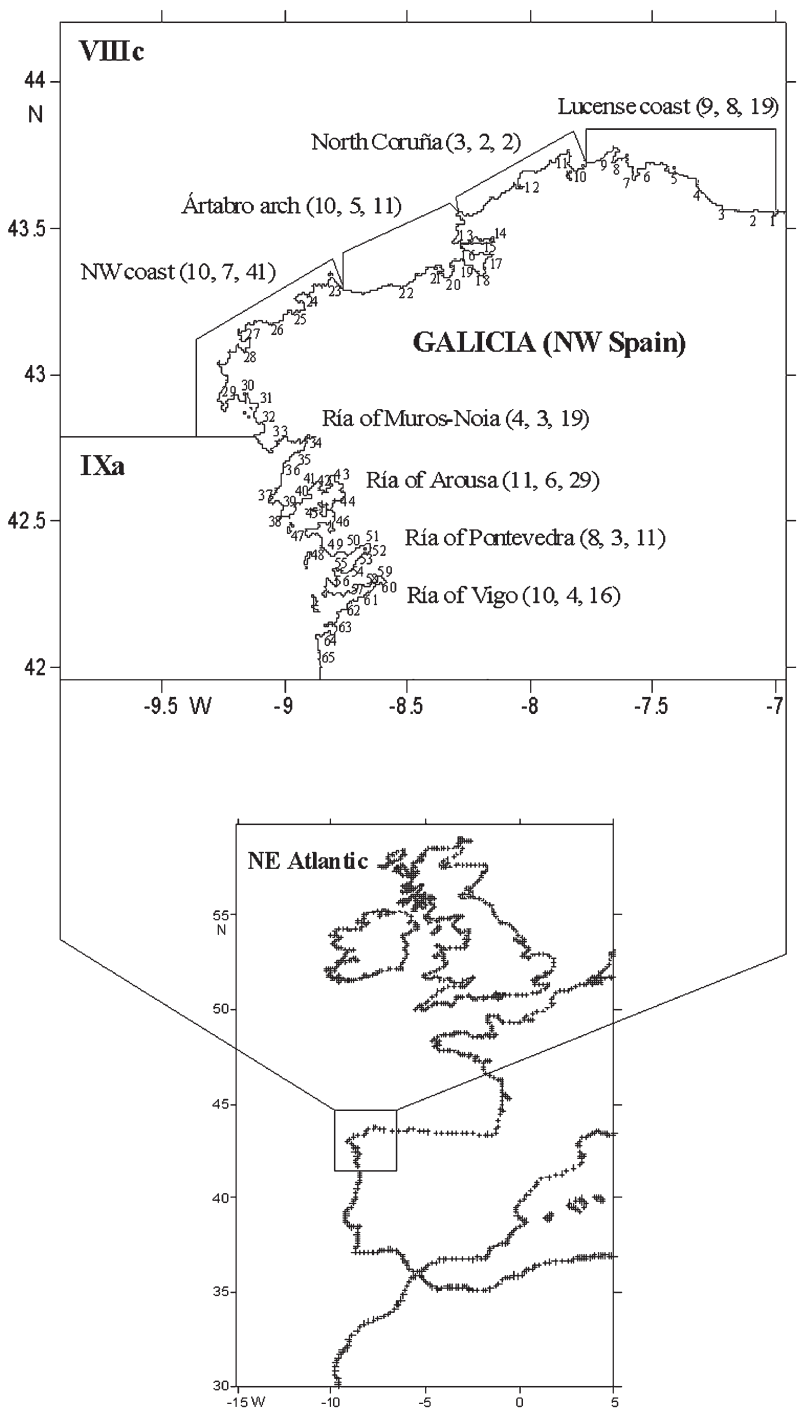

FIG. 1. - Study area (Galicia, NW Spain), divided into ICES divisions: west VIIIc and north IXa. Coastal areas belonging to these divisions are also shown. Number of ports with registered creel vessels, number of ports where interviews were made and number of interviews in each area are indicated in brackets. Numbers along the coast denote the different ports considered in this study and listed in Table 3.

\section{MATERIALS AND METHODS}

\section{Sampling program and study area}

Preliminary visits to 65 Galician (NE Atlantic) ports with registered common octopus creel vessels were conducted between January and April 1998 to establish contact with crews and determine the magnitude of the octopus fishery in terms of catches, distribution of effort and number of vessels. A total of 148 personal interviews in 38 ports, mainly with people who spend most of the season targeting the common octopus, were conducted from April 1998 to September 2000. The interviewers asked for the most recent data so these values were considered valid for the period 1997-2000.

The Galician coast was divided into two different areas (Fig. 1) corresponding to ICES divisions VIIIc (comprising the Lucense coast, Ártabro Arch, north Coruña and Northwest coast), and IXa (comprising Muros-Noia, Arousa, Pontevedra and Vigo Rías). The sampling effort in the ports of different fishing grounds was concentrated on those ports with a large number of vessels (there were more boats in the IXa area but they were much more concentrated in less ports) and a high catch variability. Moreover, logistic and funding constraints also conditioned the sampling effort. A total of 73 interviews in 22 ports in the VIIIc area and 75 interviews in 16 ports of the IXa area were conducted (Fig. 1). The suitable sample size (number of interviews, $n$ ) needed in each fishing ground was calculated according to Townend (2002), assuming that the mean catch fits a normal distribution when $\mathrm{n}$ is sufficiently large:

$$
\mathrm{n} \geq\left(\frac{\text { s.d. } * t_{\mathrm{df}, 0.05}}{\mathrm{CI}}\right)^{2}
$$

The standard deviation (s.d.) of the variable mean catch must be established according to previous samples, the value of the $t$-distribution tends to 1.96 for d.f. $=¥$ and a $95 \%$ confidence interval (CI) was considered.

\section{Applying the model}

In this study, the Gómez-Muñoz (1990) model that was modified by Rocha et al. (2004), was applied to estimate catch per unit of effort (CPUE) and total catch for the octopus creel fishery along the Galician coast. The data required for the model were obtained according to the protocol described in Rocha et al. (2004).

\section{Input parameters and variables}

Data for basic parameters that are required for input into the model, were obtained from the interviews (Table 1). A set of secondary variables that depend on the type of curve decrease, which is determined from the interview data, were also calculated. The type of curve was defined by its degree of asymmetry, measured by TE, which represents an approximation of the minimum and the maximum times within the fishing season to or from the maximum catch per haul $\left(C_{\max }\right.$, Table 1$)$. To ensure that the month with maximum catches coincides with the 
TABLE 1. - Values of the basic parameters required for input into the model for the common octopus creel fishery in both areas. The values were obtained in the interviews.

\begin{tabular}{lcc}
\hline Model parameters & VIIIc & IXa \\
\hline Month in which the fishing season starts (S) & 7 & 7 \\
Length of the fishing season in months (L) & 12 & 12 \\
Rate of decrease in catches after the peak (I) & 1 & 1 \\
Month when the maximum catch is made (M) & 12 & 1 \\
Maximum catch in one haul $\left(\mathrm{C}_{\max }\right)^{*}$ & 62.6 & 40.2 \\
Minimum catch in one haul $\left(\mathrm{C}_{\min }\right)^{*}$ & 12.7 & 7 \\
Average number of trips per month (v) & 18.8 & 19.7 \\
Mean number of hauls in a fishing trip (N) & 1.5 & 2.5
\end{tabular}

*The interviewer asked for 'mean' maximum and minimum catch in one haul $(\mathrm{kg})$ during the fishing season.

origin $(x(M)=0)$ and to make the distribution more symmetrical, the data set was time-transformed $(\mathrm{x}(\mathrm{t}))$. This variable $(\mathrm{x}(\mathrm{t}))$ has different values for each month represented in the fishing season. The term 'month' was used to calculate $\mathrm{x}(\mathrm{t})$ in all cases. The third variable is a time-weighting function $\mathrm{f}(\mathrm{x})$ that increases the weighting for the month with the maximum catch (M) and decreases it for the remaining months. These three variables were calculated according to Rocha et al. (2004).

\section{Estimating monthly CPUE and total catch}

Mean monthly catch per haul (CPUE in $\mathrm{kg}$ haul $^{-1}$ ) for an octopus creel vessel was then estimated based on a uniform distribution from:

$$
\text { CPUE }=\frac{C_{\text {max }}(f(x(t))-f(I))+C_{\text {min }}(1-f(x(t)))}{1-f(I)}
$$

Periods of 24 months were considered in order to avoid negative values. The catch determination and the distribution of CPUE are described in the Appendix of Rocha et al. (2004). The standard error of the CPUE (s.e. CPUE $_{\text {) }}$ ) was calculated according to the equation:

$$
\begin{gathered}
\text { s.e. } \mathrm{CPUE}=\frac{\mathrm{f}(\mathrm{x}) \mathrm{f}(\mathrm{I})(\max C P U E-\operatorname{minCPUE})}{\mathrm{n}+1} * \\
* \sqrt{\frac{\mathrm{nf}(\mathrm{I})^{2}-2 \mathrm{f}(\mathrm{I})+\mathrm{n}}{\mathrm{n}+2}}
\end{gathered}
$$

where $\mathrm{n}$ is the number of interviews and $\mathrm{x}(\mathrm{t})$ was substituted by $\mathrm{x}$ to simplify the equation.

The total catch per month $\left(\mathrm{C}_{\text {tot }}\right.$ in $\left.\mathrm{kg}\right)$ was estimated by the equation:

$$
\mathrm{C}_{\mathrm{tot}}=\mathrm{CPUE} * \mathrm{~N} * \mathrm{v}
$$

where $\mathrm{N}$ is the mean number of hauls per trip and $\mathrm{v}$ is the mean number of trips per month (Table 1). The standard error of the $\mathrm{C}_{\text {tot }}$ (s.e. Ctot $_{\text {. }}$ ) was calculated according to the equation:

$$
\begin{aligned}
\text { s.e. } \operatorname{Ctot}= & \frac{\mathrm{f}(\mathrm{x}) \mathrm{f}(\mathrm{I})\left(\operatorname{maxC}_{\mathrm{tot}}-\operatorname{minC}_{\mathrm{tot}}\right)}{\mathrm{n}+1} \\
& * \sqrt{\frac{\mathrm{nf}(\mathrm{I})^{2}-2 \mathrm{f}(\mathrm{I})+\mathrm{n}}{\mathrm{n}+2}}
\end{aligned}
$$

Finally, the total catch (CT in t) for the fishing fleet over the entire fishing season in each port was estimated as follows:

$$
\mathrm{CT}=\left(\sum_{1}^{\mathrm{L}} \mathrm{C}_{\mathrm{tot}}\right) * \mathrm{~B}
$$

where the summation goes from January (1) to December $(\mathrm{L})$ and $\mathrm{B}$ is a parameter that converts the fishery into a mono-species fishery. B measures the effort in each port, by means of the effective number of "virtual vessels" in the fleet per port that fish $O$. vulgaris. As the artisanal fleet is characterized by being multi-gear and due to the lack of information about a precise schedule that describes when a vessel is using each gear (see introduction), B was estimated using the information gathered from the registered boats in the Galician fisheries official website (www.pescade galicia.com) up to September 2000. Thus, the number of virtual vessels exclusively targeting $O$. vulgaris was estimated by considering the number of gear types which each vessel can use ( $\mathrm{n}^{\mathrm{o}}$ of gears registered), and assuming that a vessel expends equal fishing effort with each gear type (i.e. a vessel with two different registered gears has a value of 0.5 ). Then $\mathrm{B}$ was estimated by adding up the number of virtual octopusfishing vessels in each port.

Total common octopus catch for the whole Galician artisanal fleet was then obtained by up the catches from each port (CT) during the fishing season.

\section{Outliers}

These were identified according to Rocha et al. (2004), and by displaying box-and-whiskers plots using STATISTICA 6.

\section{Comparing estimated catches and official data}

To test the reliability of the model the outputs were correlated with the available official data in a subset of 35 ports (19 in VIIIc and 16 in IXa). First 
TABLE 2. - Monthly CPUE (in $\left.\mathrm{kg} \mathrm{haul}^{-1}\right)$ and total catch $\left(\mathrm{C}_{\text {tot }}\right.$ in $\mathrm{kg}$ ) for an octopus creel vessel estimated by the model. s.e.: Standard error of CPUE and total catch.

\begin{tabular}{lcccr}
\hline & \multicolumn{2}{c}{ VIIIc } & \multicolumn{2}{c}{ IXa } \\
& CPUE & $\mathrm{C}_{\text {tot }}$ & CPUE & $\mathrm{C}_{\text {tot }}$ \\
\hline January & 60.9 & 1716 & 40.2 & 1979.8 \\
February & 55.7 & 1572.1 & 38.5 & 1897.6 \\
March & 47.7 & 1345.1 & 33.7 & 1660.4 \\
April & 37.3 & 1052.7 & 26.3 & 1295.3 \\
May & 25.4 & 716.2 & 17.1 & 841.8 \\
June & 12.7 & 358.1 & 7 & 344.8 \\
July & 25.4 & 716.2 & 0.5 & 24.1 \\
August & 37.3 & 1052.7 & 7 & 344.8 \\
September & 47.7 & 1345.1 & 17.1 & 841.8 \\
October & 55.7 & 1572.1 & 26.3 & 1295.3 \\
November & 60.9 & 1716 & 33.7 & 1660.4 \\
December & 62.6 & 1765.3 & 38.5 & 1897.6 \\
Mean & 44.11 & 1243.9 & 23.83 & 1173.6 \\
s.e. & 1.8 & 51.4 & 1.4 & 69.7 \\
\hline
\end{tabular}

of all, smoothed monthly trends using a two-point moving average of the estimated total catch (CT in t) for both areas combined were compared with twopoint moving average of the mean monthly official catch from 1998 to 2000 (Co in t). Secondly, the estimated total catch (CT) in each of the 35 ports was correlated with official statistics of the average annual catch from 1997 to 2000 (Co). The Pearson correlation was then used.

\section{RESULTS}

A total of 148 interviews focused on the octopus small-scale fishery were carried out in 38 selected Galician ports. Within these, 73 interviews were conducted with fishermen operating in VIIIc waters, and 75 with fishermen operating in IXa waters (Fig. 1). Considering the true population s.d. $=45.4 \mathrm{~kg}$ in VIIIc waters and that there is $95 \%$ confidence of it being within $11 \mathrm{~kg}$ of the true value, the minimum sample size required ( $n^{\circ}$ of interviews) is $n \geq 65$. In IXa waters the s.d. $=33.8 \mathrm{~kg}$ and there is $95 \%$ confidence of it being within $8 \mathrm{~kg}$ of the true value, so the minimum sample size required is $n \geq 69$.

Table 1 shows the basic model input parameter values, estimated from interviews for both fishing grounds. Model estimates of monthly CPUE, total catch $\left(\mathrm{C}_{\mathrm{tot}}\right)$, mean monthly values as well as their standard errors (s.e.) are shown in Table 2. Figure 2 shows the seasonal CPUE curves for a common octopus creel vessel in the VIIIc and IXa divisions during the fishing season. Both CPUE trends estimated by the model, show a slow decrease to the end of the fishing season (Type 1 curve) with the maxi-

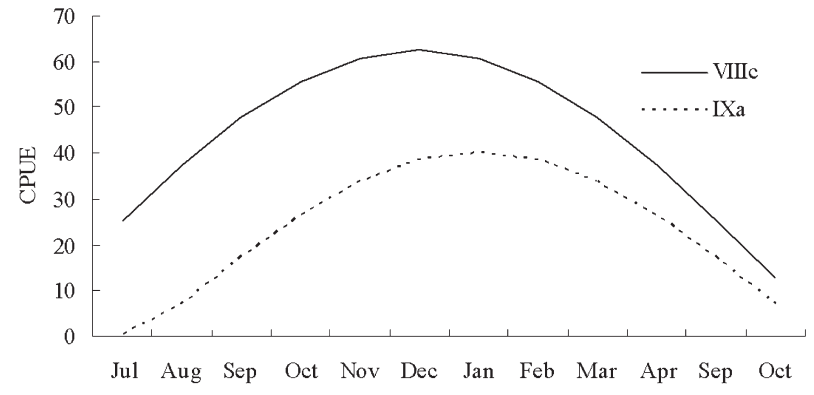

FIG. 2. - Time course of the CPUE $\left(\mathrm{kg} \mathrm{haul}^{-1}\right)$ for an octopus creel vessel during the fishing season in ICES divisions VIIIc and IXa.

mum CPUE in December and January for the VIIIc and IXa areas respectively.

The $O$. vulgaris fishery in the VIIIc area was exploited by 169 "virtual vessels" in 32 ports, whereas 191 "virtual vessels" operated in 33 ports in the IXa area (Table 3). The mean, maximum and minimum total catch (the last two not shown) for the two common octopus fisheries were calculated based on the model estimates as well as considering the measure of effort in each port (B). The total catch estimated by the model for VIIIc and IXa creel fisheries was $2528 \mathrm{t}$ and $2686 \mathrm{t}$ respectively (Table 3 ).

Official octopus catch statistics were available from 35 ports, which represent about $54 \%$ of the ports, which contain $77.5 \%$ of the registered vessels using creels for common octopus. Monthly trends of the estimated total catch (CT) for both areas combined were significantly correlated with the average monthly official catches (Co) from 1998 to 2000 $(r=0.77, p=0.009)$ (Fig. 3). Furthermore, the average official catch (Co) from 1997 to 2000 and estimated total catch (CT) data were significantly correlated in the VIIIc division $(r=0.69, p=0.001, n=19)$ (Fig. $4 \mathrm{~A})$, and the IXa division ( $r=0.71, p=0.002, n=16)$ (Fig. 4B).

\section{DISCUSSION}

Studies using interview data provide a large amount of information that is considered as a useful tool for assessing fisheries (Neis et al., 1999). It is essential that scientists and local fishers communicate to develop the framework for providing scientific advice for managing new and developing invertebrate fisheries (Perry et al., 1999). Other studies of invertebrate fisheries in the Galician region have integrated fishers in the assessment and management processes (Molares and Freire, 2003). The results obtained can be used to generate an informa- 
TABLE 3. - Mean estimated total annual catch (CT in t) for each port in the VIIIc and IXa areas which represent the whole Galician fleet, obtained by the model during the fishing season. B: number of "virtual vessels" in each port (see text). Co: Mean catch in t obtained from official sources for years 1997-2000. Numbers indicate the location of each port along the Galician coast (see Fig. 1).

\begin{tabular}{|c|c|c|c|c|c|c|c|}
\hline \multirow[b]{2}{*}{ Port } & \multicolumn{2}{|r|}{ VIIIc } & \multirow[b]{2}{*}{$\mathrm{Co}$} & \multirow[b]{2}{*}{ Port } & \multicolumn{2}{|c|}{ IXa } & \multirow[b]{2}{*}{$\mathrm{Co}$} \\
\hline & B & $\mathrm{CT}$ & & & B & $\mathrm{CT}$ & \\
\hline${ }^{21} \mathrm{~A}$ Coruña & 15.57 & 232.4 & 203.7 & ${ }^{65} \mathrm{~A}$ Guarda & 10.45 & 147.2 & 18.3 \\
\hline${ }^{16}$ Ares & 1.53 & 22.8 & & ${ }^{45} \mathrm{~A}$ Illa de Arou. & 3.07 & 43.2 & \\
\hline${ }^{14}$ Barallobre & 0.9 & 13.4 & & ${ }^{41}$ A Pobra & 3.53 & 49.7 & \\
\hline${ }^{4}$ Burela & 6.58 & 98.2 & 122.1 & 56Aldán-Hío & 4.87 & 68.6 & 27.5 \\
\hline${ }^{22}$ Caión & 3.33 & 49.7 & 52.6 & ${ }^{64}$ Baiona & 16.35 & 230.3 & 151.5 \\
\hline${ }^{27}$ Camariñas & 15.35 & 229.1 & 65.7 & ${ }^{62}$ Bouzas & 0.5 & 7 & \\
\hline${ }^{26}$ Camelle & 14.98 & 223.6 & & ${ }^{55} \mathrm{Bueu}$ & 19.58 & 275.8 & 278.5 \\
\hline${ }^{11}$ Cariño & 5.25 & 78.4 & 42.9 & ${ }^{42} \mathrm{Cabo}$ de Cruz & 0.65 & 9.1 & \\
\hline${ }^{12}$ Cedeira & 6.5 & 97 & 103.7 & ${ }^{46} \mathrm{Cambados}$ & 8.13 & 114.5 & 20.1 \\
\hline${ }^{6}$ Celeiro & 4.05 & 60.5 & 9.6 & ${ }^{52}$ Campelo & 1.9 & 26.8 & \\
\hline${ }^{30}$ Corcubión & 4.25 & 63.4 & & ${ }^{57}$ Cangas & 20.2 & 284.5 & 46.4 \\
\hline${ }^{24}$ Corme & 3.12 & 46.6 & 21.4 & ${ }^{38}$ Carre.-Aguiño & 6.27 & 88.3 & 1.2 \\
\hline${ }^{10}$ Espasante & 2.38 & 35.5 & 7.9 & ${ }^{51}$ Combarro & 2.35 & 33.1 & \\
\hline${ }^{29}$ Fisterra & 12.55 & 187.3 & 112.3 & ${ }^{37}$ Corrubedo & 2.63 & 37 & \\
\hline${ }^{3} \mathrm{Foz}$ & 1.48 & 22.1 & 24.1 & ${ }^{54}$ Marín & 4 & 56.3 & \\
\hline${ }^{25} \mathrm{Laxe}$ & 10.17 & 151.8 & 37.3 & ${ }^{59}$ Meira & 0.2 & 2.8 & \\
\hline${ }^{32}$ Lira-Carn. & 7.28 & 108.7 & 92.4 & ${ }^{58}$ Moaña & 5.58 & 78.6 & 47.6 \\
\hline${ }^{19}$ Lorbé & 4.35 & 64.9 & & ${ }^{33}$ Muros & 4.8 & 67.6 & 200.2 \\
\hline${ }^{23}$ Malpica & 16.6 & 247.8 & 258.2 & ${ }^{34}$ Noia & 7.83 & 110.3 & \\
\hline${ }^{20}$ Mera-Olei. & 2.05 & 30.6 & & ${ }^{47} \mathrm{O}$ Grove & 11.2 & 157.7 & 56.8 \\
\hline${ }^{15}$ Mugardos & 0.33 & 4.9 & & ${ }^{40} \mathrm{Palmeira}$ & 0.85 & 12 & \\
\hline${ }^{28}$ Muxía & 9.05 & 135.1 & 22.8 & ${ }^{63}$ Panxón & 0.73 & 10.3 & \\
\hline${ }^{9} \mathrm{O}$ Barqueiro & 2.77 & 41.3 & & ${ }^{53}$ Pontevedra & 2.08 & 29.3 & \\
\hline${ }^{13} \mathrm{O}$ Ferrol & 8.7 & 129.9 & & 36Porto do Son & 6.53 & 92 & 108.3 \\
\hline${ }^{31} \mathrm{O}$ Pindo & 1.75 & 26.1 & & ${ }^{48}$ Portonovo & 5.18 & 73 & 38.9 \\
\hline${ }^{8} \mathrm{O}$ Vicedo & 0.8 & 11.9 & 0.04 & ${ }^{35}$ Portosín & 1.25 & 17.6 & 0.02 \\
\hline${ }^{17}$ Pontedeu. & 0.98 & 14.6 & & ${ }^{50}$ Raxó & 1.18 & 16.6 & \\
\hline${ }^{1}$ Ribadeo & 1.77 & 26.4 & 22.8 & ${ }^{60}$ Redondela & 0.2 & 2.8 & \\
\hline${ }^{2}$ Rinlo & 0.2 & 2.9 & & ${ }^{43}$ Rianxo & 0.58 & 8.2 & 2.2 \\
\hline${ }^{18} \mathrm{Sada}$ & 1.28 & 19.1 & 1.2 & ${ }^{39}$ Ribeira & 27.77 & 391.1 & 531.5 \\
\hline${ }^{5}$ San Cibrao & 3.25 & 48.5 & 157 & ${ }^{49}$ Sanxenxo & 4.1 & 57.7 & \\
\hline${ }^{7}$ Viveiro & 0.2 & 2.9 & & ${ }^{61}$ Vigo & 5.45 & 76.8 & 278 \\
\hline & & & & ${ }^{44}$ Vilanova & 0.7 & 9.9 & \\
\hline Total & 169.4 & 2528 & 1358 & Total & 190.7 & 2686 & 1807 \\
\hline
\end{tabular}

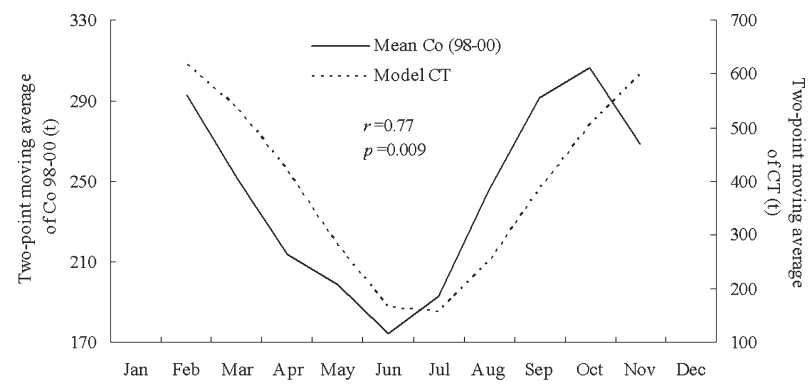

FIG. 3. - Comparison of the two-point moving average of monthly trends of estimated total catch $(\mathrm{CT})$ and the two-point moving average of the monthly mean official catch (Co) for years 1998-2000. Both areas were pooled.

tion base for local and regional fisheries for which there is not much quantitative scientific data (Neis et al., 1999).

The simple model developed by Gómez-Muñoz (1990), for multi-species small-scale fisheries is not an assessment and management model but rather a tool that is used to evaluate the fishery status and performance based on data obtained from resource users. The special characteristics of Galician smallscale fisheries made this model applicable as a method for estimating CPUE and the total catch for the entire fishery, as well as for comparison of model estimates with the official fishery statistics available. Considering that the model estimates compare well with official fishery data in our study, as well as in other studies (Simón et al., 1996; Rocha et al., 2004), we conclude that the model is both appropriate and reliable.

Since the information is based on interviews with fishermen, their memory and the possibility of different interpretations of parameters are two of the key factors for running the model appropriately. Thus, the interviewer must explain his/her intention exhaustively and must not subjectively interpret the information obtained. In addition, a minimum number of interviews are necessary due to the complexity of Galician artisanal fisheries (which are multispecies and multi-gear), the large number of ports involved and the variability of the catches. These 

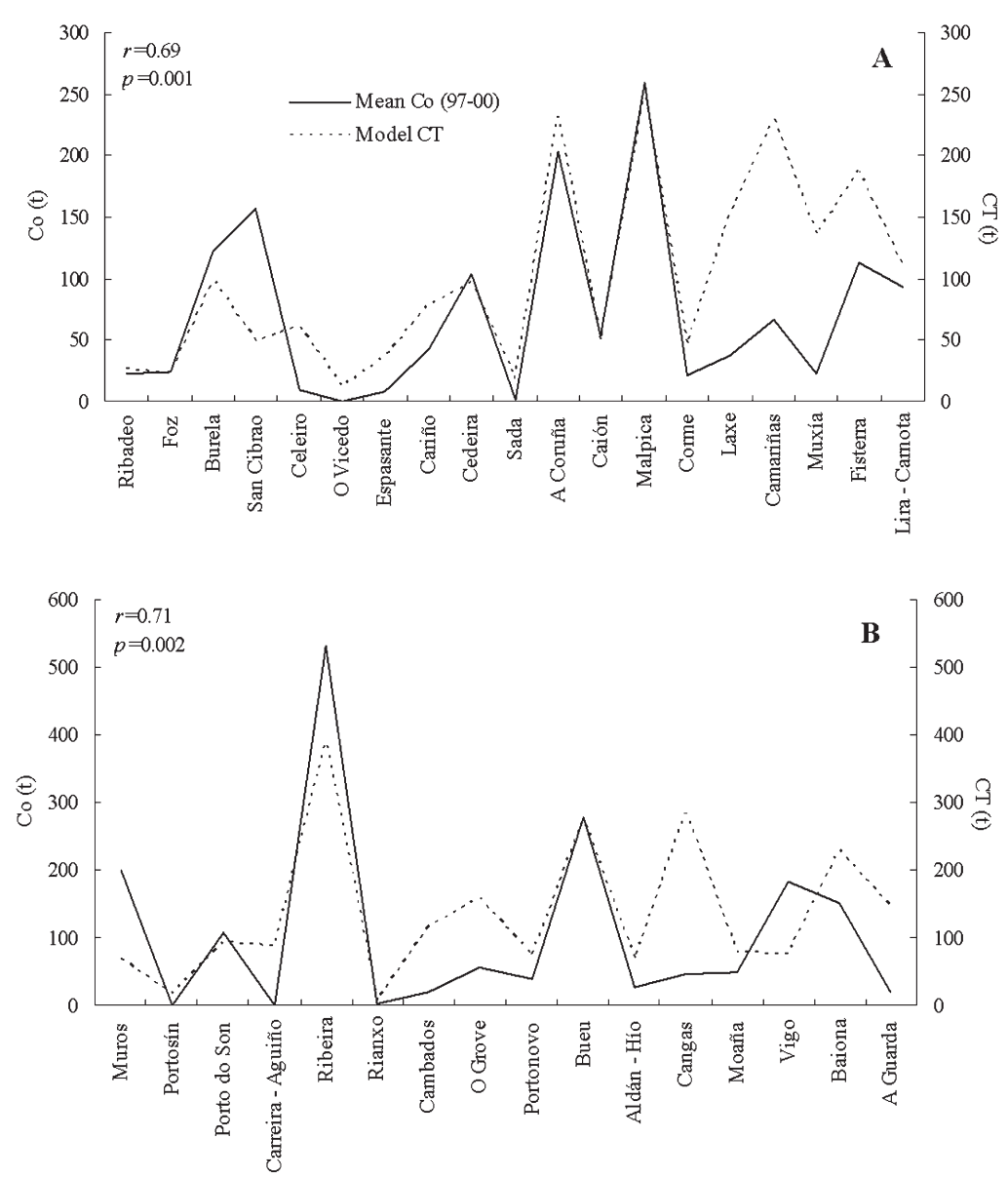

FIG. 4. - Comparison of the estimated total catch (CT) and average official annual catch (Co) for years 1997-2000 in each port belonging to ICES divisions VIIIc (A) and IXa (B).

conditions were brought together in our study, which resulted in an accurate estimation of model parameters and eliminated incoherent and unreasonably extreme data (outliers) according to the methodology presented by Rocha et al. (2004). Moreover, we carefully measured the effort in terms of "virtual number of vessels" in each port, using the most accurate available method. In fact, the 360 estimated virtual vessels exclusively targeting $O$. vulgaris throughout the fishing season is not so far from the data considered by the autonomous government (R. Arnaiz, UTPB, pers. com.).

The octopus creel fishery in Galicia constitutes an important socioeconomic activity, and targets one of the main invertebrate species exploited. It yields an average of $4000 \mathrm{t}$ per year (Freire and GarcíaAllut, 2000). However, in other Spanish areas, such as the Canary Islands and the Mediterranean coast, the artisanal octopus fishery (including pots, traps and fyke nets) is less important (Sánchez and Obarti, 1993; Hernández-García et al., 1998; Tsangridis et al., 2002). On the Portuguese coast, the small-scale trap and pot fishery is traditionally the most common method of catching octopuses. Landings made with these gears accounted for about $79 \%$ of the total annual catch of about $8600 \mathrm{t}$ during 1988-97 (Pereira, 1999). The octopus fishery off Senegal's coast, exploited by artisanal methods, yielded about $8160 \mathrm{t}$ in 1991 (Diallo and Ortiz, 2002).

Managing the Galician small-scale fisheries is difficult due to the fisheries' great complexity (Freire and García-Allut, 2000). Since 1994, the Galician government has run a fisheries information service which is in charge of updating the official statistics, see above. We collected the available data in 35 Galician ports (54\%), which included $77.5 \%$ of the boats with permission to use common octopus creel gear from that source. One of the problems is that most of the fishery data, which also occurs for other invertebrate species, are highly fragmentary and incomplete (Molares and Freire, 2003), even though it is obligatory for the fishery associations ("Cofradías") to provide this information to the autonomous government (DOG, 11/08/2004). By 
applying the Gómez-Muñoz model we were able to estimate the catches in the 65 ports that have registered creel vessels. This model is also capable of estimating reported, unreported and misreported data (Rocha et al., 2004).

This study found a marked seasonality in the Galician octopus catches per unit of effort, with the highest values occurring during winter for both fishing grounds (Fig. 2). Moreover, the monthly trends of estimated total catch for the whole Galician coast (CT) were correlated with official data (Co) (Fig. 3). In more temperate areas, the maximum values occur earlier. Thus, in the Canary Islands HernándezGarcía et al. (1998), observed two peaks of octopus catches in spring and autumn. Along the Spanish Mediterranean coast, catches obtained by artisanal gear types are high between April and June (Tsangridis et al., 2002), whereas in Senegal there is a peak in summer (Diallo and Ortiz, 2002). It is worth noting that we obtained a similar total catch (CT) for both fishing grounds (Table 3 ) in spite of the average number of trips, mean number of hauls (Table 1) and virtual vessels being lower in the northern area of Galicia than in the southern area (Table 3). This could possibly be explained by the stock availability in the northern fishing ground being higher than in the southern fishing ground, in spite of the more adverse weather conditions on the northern coast, which obviously reduce the fishing activity in this area.

There are two main discrepancies between estimated data and official sources. First of all, we estimated a volume of almost $5200 \mathrm{t}$ per year for the whole Galician common octopus creel fishery, whereas the average official catch is around $4000 \mathrm{t}$ per year. This would mean that some of the catches are not reported. Another possibility is that an unknown percentage of the catches is sold out of auction and is therefore not recorded in the official statistics. In the Galician monkfish fishery, the Gómez-Muñoz model over-estimated the reported catch by an insignificant $12.3 \%$, which probably represents the unreported catch (Rocha et al., 2004). Secondly, there are some port-specific differences. This may be partially because some vessels land their catches in different ports within the same year (i.e. vessels that are registered in a specific port, land in another one from the same geographically area). Despite these general and port-specific discrepancies, it is noteworthy that the official total catch data in these 35 ports concerning the average monthly trends from 1998 to 2000, the annual catch from 1997 to 2000 (Co) and the estimated total catch (CT), were significantly correlated for the whole coast (Fig. 3) and for ports in the VIIIc (Fig. 4A) and IXa (Fig. 4B) divisions.

On the whole, the model applied in this paper can be used as an independent tool for estimating catch and effort in any given fishery, and testing the reliability of landing statistics. When there are no catch statistics, the Gómez-Muñoz model is also a useful tool for generating data for any fishery, and constitutes a first step in assessing an exploited resource. However, even when the catch levels are known the management of the small-scale fisheries must be improved. In this sense, the proposals outlined in Freire and García-Allut (2000), for researching and developing sustainable management strategies and new policies to be applied by the administration, represent an alternative framework that must be developed in the future.

\section{ACKNOWLEDGEMENTS}

We thank J. Castro for dealing with the interviews and M.T. Fernández, E. Ledo and M.C. Rodríguez for their technical support. We are indebted to the fishermen, skippers and other people related to the fishing sector who were interviewed for their collaboration. Dr. E.G. Dawe made very helpful comments on the manuscript and Dr. J. Lleonart and three anonymous reviewers shed light on some key points. This study was funded by the EU Projects CE 97/0107 and CFP 99/063. J. Otero was supported by a grant awarded by the Diputación de Pontevedra.

\section{REFERENCES}

Caddy, J.F. - 1999. Fisheries management in the twenty-first century: will new paradigms apply? Rev. Fish Biol. Fisheries., 9: $1-43$.

Diallo, M. and M. Ortiz. - 2002. Estimation of a standardized index of abundance of octopus $(O$. vulgaris) from the Senegalese's artisanal fishery (1989-1994). In: A. Caverivière, M. Thiam and D. Jouffre (eds.), Le poulpe Octopus vulgaris. Sénégal et côtes nord-ouest africaines, pp. 223-232. Institut de Recherche pour le Développement, Paris.

Freire, J. and A. García-Allut. - 2000. Socioeconomic and biological causes of management failures in European artisanal fisheries: the case of Galicia (NW Spain). Mar. Policy., 24: 375-384.

Freire, J., C. Bernárdez, A. Corgos, L. Fernández, E. GonzálezGurriarán, M.P. Sampedro and P. Verísimo. - 2002. Management strategies for sustainable invertebrate fisheries in coastal ecosystems of Galicia (NW Spain). Aquat. Ecol., 36: 41-50.

Gómez-Muñoz, V.M. - 1990. A model to estimate catches from a short fishery statistics survey. Bull. Mar. Sci., 46: 719-722. 
Guerra, A. - 1997. Octopus vulgaris: Review of the world fishery. In: M.A. Lang and F.G. Hochberg (eds.), Proceedings of the workshop on the fishery and market potential of Octopus in California, pp. 91-97. Smithsonian Institution, Washington D.C.

Hatanaka, H. - 1979. Studies on the fisheries biology of common octopus off the northwest coast of Africa. Bull. Far Seas Fish. Res. Lab. 17: 13-124.

Hernández-García, V., J.L. Hernández-López and J.J. Castro. 1998. The octopus (Octopus vulgaris) in the smale-scale trap fishery off the Canary Islands (Central-East Atlantic). Fish. Res., 35: 183-189.

Hoening, J.M., C.M. Jones, K.H. Pollock, D.S. Robson and D.L. Wade. - 1997. Calculation of catch rate and total catch in roving surveys of anglers. Biometrics., 53: 306-317.

Josupeit, H. - 2000. Los mercados mundiales de cefalópodos. Product. Mar., 12: 43-48.

Jouffre, D., S. Lanco, D. Gascuel and A. Caverivière. - 2002. Niveaux d'exploitation des stocks de poulpes du Sénégal de 1996 à 1999 et tailles minimales de captures. Une évaluation par modélisation analytique. In: A. Caverivière, M. Thiam and D. Jouffre (eds.), Le poulpe Octopus vulgaris. Sénégal et côtes nord-ouest africaines, pp. 269-295. Institut de Recherche pour le Développement, Paris.

Kirchner, C.H. and J.E. Beyer. - 1999. Estimation of total catch of Silver Kob Argyrosomus inodorus by recreational shoreanglers in Namibia using a roving-roving creel survey. S. Afr. J. Mar. Sci., 21: 191-199.

Molares, J. and J. Freire. - 2003. Development and perspectives for community-based management of the goose barnacle (Pollicipes pollicipes) fisheries in Galicia (NW Spain). Fish. Res., 65: 485-492.

Neis, B., D.C. Schneider, L. Felt, R.L. Haedrich, J. Fischer and J.A Hutchings. - 1999. Fisheries assessment: what can be learned from interviewing resource users?. Can. J. Fish. Aquat. Sci., 56: 1949-1963.

Pereira, J.M.F. - 1999. Control of the Portuguese artisanal octopus fishery. In: C.P. Nolan (ed.), Proceedings of the International Conference on Integrated Fisheries Monitoring, pp. 369-378. FAO, Rome.

Pereiro, J.A. and J. Bravo de Laguna. - 1979. Dinámica de la población y evaluación de los recursos del pulpo del Atlántico Centro-Oriental. Bol. Inst. Esp. Oceanogr., 5: 69-105.

Perry, R.I., C.J. Walters and J.A. Boutiller. - 1999. A framework for providing scientific advice for the management of new and developing invertebrate fisheries. Rev. Fish Biol. Fisheries., 9: $125-150$.

Pollock, K.H., J.M. Hoening, C.M. Jones, D.S. Robson and C.J. Greene. - 1997. Catch rate estimation for roving and access point surveys. N. Am. J. Fish. Manag., 17: 11-19.

Quetglas, A., F. Alemany, A. Carbonell, P. Merella and P. Sánchez. - 1998. Biology and fishery of Octopus vulgaris Cuvier, 1797, caught by trawlers in Mallorca (Balearic Sea, Western Mediterranean). Fish. Res., 36: 237-249.

Rocha, F., J. Gracia, A.F. González, C.M. Jardón and A. Guerra. 2004. Reliability of a model based on a short fishery statistics survey: application to the Northeast Atlantic monkfish fishery. ICES J. Mar. Sci., 61: 25-34.

Sánchez, P. and R. Obarti. - 1993. The biology and fishery of Octopus vulgaris caught with clay pots on the Spanish Mediterranean Coast. In: T. Okutani, R.K. O'Dor and T. Kubodera (eds.), Recent advances in fisheries biology, pp. 477487. Tokai University Press, Tokyo.

Simón, F., F. Rocha and A. Guerra. - 1996. The small-scale squid hand-jig fishery off the northwestern Iberian Peninsula: application of a model based on a short survey of fishery statistics. Fish. Res., 25: 253-263.

Townend, J. - 2002. Practical statistics for environmental and biological scientists. John Wiley \& Sons, West Sussex, UK.

Tsangridis, A., P. Sánchez and D. Ioannidou. - 2002. Exploitation patterns of Octopus vulgaris in two Mediterranean areas. Sci. Mar., 66: 59-68.

Scient. ed.: J. Lleonart 
